P04

Evidence of Glacio-eustacy during the Late Berriasian to Late

Valanginian: Record in the Lekhwair/Habshan/Salil Prograding Geometries, Rayda Basin, Sultanate of Oman

E. Dujoncquoy* (Institut EGID, France), P. Razin (Institut EGID, France), C. Grélaud (Institut EGID, France), P. Imbert (TOTAL, France) \& G. Dupont (TOTAL, France) 


\title{
15118 Evidence of glacio-eustasy during the Late Berriasian to Late Valanginian: Record in the Lekhwair/Habshan/Salil prograding geometries, Rayda Basin, Sultanate of Oman
}

\author{
Emmanuel Dujoncquoy (Maersk Oil, <emmanuel.dujoncquoy@maerskoil.com>, previously \\ University of Bordeaux, France), Philippe Razin (University of Bordeaux, France), Carine Grélaud \\ (University of Bordeaux, France), Patrice Imbert (TOTAL) and Dupont Gerard (TOTAL)
}

The Lekhwair/Habshan/Salil (or LHS) system is a carbonate succession that prograded by $300 \mathrm{~km}$ toward the northeast across the eastern part of the Arabian Plate (Rayda Basin) from Berriasian to Early Barremian. The system is organized as a series of large prograding clinoforms with amplitudes ranging from 200 to $350 \mathrm{~m}$.

The three formations that compose this system correspond respectively to the inner platform (Lekhwair Formation), platform margin (Habshan Formation) and slope-to-basin facies associations (Salil Formation). On seismic sections, this system shows a conspicuous prograding character with wellexpressed clinoforms (Berriasian to Valanginian). The formations imaged on the seismic section are exposed at outcrop in the Oman Mountains (Upper Valanginian to Lower Barremian) to the north, making it possible to study the system at different scales: basin, depositional system and reservoir.

This study focuses on the basin-scale evolution from Berriasian to Valanginian. It is based on the stratigraphic interpretation of a regional 2-D/3-D seismic dataset. It covers a region located in the northern part of Oman, extending $140 \mathrm{~km}$ from north to south and $280 \mathrm{~km}$ from east to west.

Calpionellids biostratigraphic study from core data allowed a time-calibration for the interpreted seismic sequences. Four sequence groups have been defined for the period from the Berriasian to the Late Valanginian. (1) The Upper Berriasian sequence group, which records cycles of high-amplitude relative sea-level variations. (2) The Uppermost Berriasian-Base Valanginian sequence group records cycles of lowest amplitude relative sea-level variations. (3) The Lower to Mid-Valanginian sequence group, records a cycle of high-amplitude relative sea-level variation, in which the rising sea-level phase is manifested as large aggrading-prograding wedges. This unit is characterized by the preservation of vast inner-platform deposits covering the whole of the underlying sequence groups (equivalent of the Zakum Member in the United Arab Emirates). (5) The Mid- to Upper Valanginian sequence group records a series of cycles of lower-amplitude relative sea-level variations, which are generally manifested as a regional phase of pure progradation.

Based on seismic stratigraphy and geomorphology, relative sea-level changes were interpreted as the main factor controlling the geometries. The good correlation between the interpreted relative sea level cycles and eustatic curve published by Haq et al. (1988) suggests eustasy as the main controlling factor for the architecture of the LHS clinoform system. The alternation between high- and low- amplitude cycles suggests a climatic control for these eustatic cycles.

\section{References}

Haq, B.U., J. Hardenbol and P.R. Vail 1988. Mesozoic and Cenozoic chronostratigraphy and eustatic cycles. In C.K. Wilgus, B.S. Hastings, C.G.St.C. Kendall, H.W. Posamentier, C.A. Ross, J.C. Van Wagoner (Eds.), Sealevel Changes: An Integrated Approach. Society of Economic Palaeontologists and Mineralogists, Special Publication no. 42, p. 71-108. 